Book Review - 2

\title{
A method does not deskill teachers, rather it empowers them.
}

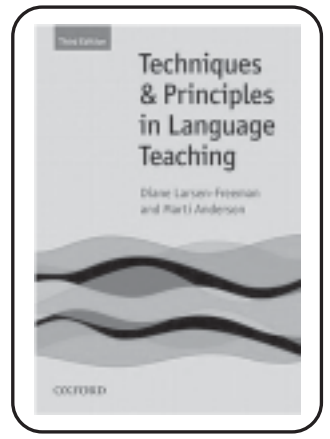

Larsen-Freeman, D. (2000, second edition).Techniques and Principles of Language Leaching.Oxford, UK: Oxford University Press, Pages: 189. Price- U\$ 80.ISBN: 9780194423601

\section{Introduction}

Every teacher has certain thought in their mind and they use the thoughts into actions that is, in teaching and learning language. According to Larsen- Freeman, 'the actions are the techniques and thoughts are the principles' (p. 1). From the combination of these two terms, she named a book entitled "Techniques and Principles in Language Teaching" which aims to uncover the thoughts of teachers or language educators on which they stand to carry out the action; and, to introduce the variety of teaching techniques for language teaching and learning. Though the book contains only 189 pages, it is an appropriate and illuminating gift for the language teacher and educator in terms of language teaching methods and techniques.

\section{Background information}

This book is based on the personal experience of Diane Larsen-Freeman in teaching the methods and approaches course at the school of international training. As stated above, she wants to go to the field and see how the action and thought are linked together. In other words, how language teaching method is practiced. There are 12 chapters in the book. The first chapter is an introduction chapter in which she describes the overview of the book in general. From chapter two to nine, there is a detailed explanation of only one method in each chapter. Chapter number is arranged on the basis of gender: 'in the even number of chapter, the teacher is female; in the odd number chapter, the teacher is male'(p. 8). All the chapters start with the introduction of the method, followed by real classroom experience. Then, she writes about her observation and draws the principle out of the observation. After that, she has set 10 questions to check the general understanding of the readers. She 
asks about goal, role of teachers and students, characteristic of teaching and learning process, nature of teacher student interaction and student to student interaction, feeling of the students, view on language and culture, skill and aspect focused, role of students native language, techniques of evaluation and views on errors respectively. She revises the techniques adopted by the teachers in teaching the real classroom. At last, she draws conclusion of the chapter followed by two types of question: checking understanding and application in real life situation. But, chapter ten and eleven consists of three methods. Chapter ten is grouped on the basis of the theme that language can be best learnt through communication whereas chapter eleven on the theme that language acquisition can be enhanced by working not only the language but also the process of learning. In these two chapters, techniques, conclusion and activities are not clearly stated. In chapter twelve, she has modified the previous edition's 'epilogue' into conclusion chapter of its own.

She has discussed on grammar translation method in chapter two. In it, she observed highintermediate level English class at a university in Colombia where 42 students were taught two hours classes three times in a week. By the observation of the class, she has drawn the principles and suggested the possible techniques used in the method. In chapter three, she has discussed about the direct method. It is a method of teaching foreign or second language in which 'meaning is to be conveyed directly in the target language through the use of demonstration and visual aids with no recourse to the students native language'.( Diller, 1978 as cited in p. 23). For this, she has observed a lower secondary school level English teacher's class in Italy. The class had 30 students who attended English class for one hour, three times a week. On the basis of her observation, she has developed principles and recommended techniques for foreign language teaching.

Chapter four is on Audio-Lingual method. It is a method of teaching foreign or second language teaching in which language is learnt through conditioning- direct association between stimulus, response and reinforcement. In order to understand this method, she has observed beginning level English class in Mali. There were 34 students of 13 to 15 years of age. The class met one hour a day, five days in a week. From her observation, she has drawn principles of language teaching and suggested drill and pattern practice as main techniques of language learning and teaching. Similarly, she has explained silent way, desuggestopedia, community language learning and total physical response in chapter 5,6,7 and 8 respectively.

Chapter nine is about communicative method; the current foreign language teaching method which aims to develop communicative competence of learners by communicating in the target language. She has visited a class being conducted for adult immigrants to Canada. These 20 people had lived in Canada for two years and were at a high -intermediate level of English proficiency. They met two evenings a week for two hours each class. She has observed the class and drawn principles. She has advised five techniques of it: authentic materials, scrambled sentences, language games, picture strip story and role play. In chapter ten, content-based, task based and participatory approaches are discussed. Though these methods make communication as central but there is slight difference between communicative method and these approaches. It is a matter of focus. These methods do not begin with language function. Instead, they give priority to process over predetermined linguistic content. In these approaches, students use English to learn content rather that leaning to use English.(Howatt 1984). Learning strategy training, cooperative learning, and multiple intelligences are not comprehensive method of language teaching, but they 
complement the others method and reflect interesting methodological practice. The last chapter presents the summary chart of the entire chapters. Different methods are vividly compared and contrasted followed by selecting the language teaching method in a classroom teaching. He concludes the book with the development of the methodology.

\section{Evaluation}

Everything has positive and negative aspects. This book is evaluated in terms of reader's perspectives.

\section{Positive aspects}

I. Real experience: - the writer goes into the real classroom to observe the teaching and learning activities of the teacher and students and then she draws conclusions from there. So, this book is the product of real experience.

II. Practicality: all the principles and techniques described in the book are still in use in teaching and learning activities in the classroom because it is a practical outcome of her experiences.

III. Content: the contents are presented in chronological order; method that were used in past till the present.

IV. Level of difficulty: the language she has used is simple. Not only the language teacher but general students also can easily comprehend the content.

V. Purpose of writing: her purpose was to teach how to put the thoughts into action. She is able to do so by practically observing the class the deriving the principles and techniques out of it.

VI. Layout: since I have only digital photocopy of the book, I can't say more about it. However, it's size and design is comfortable for the readers.

VII. Date: though this book has been published in 2000, it talks about the current methods and techniques used in language teaching and learning today.

\section{Negative aspects}

I. Unconvincing: teachers do not think about the method while they are planning their lesson (Long, 1990) because methodological level tells us little about what really occurs in the classroom.

II. Prescription of classroom behavoiurs: only one method and technique is not applicable in all classrooms in the world. It might vary according to the context. The context of Canada and Nepal is totally different. The thing that is perfectively applicable in Canada can be failure in Nepal. So prescribing technique in terms of observation in one context does not fit in others. 
III. Search for the best method is ill-advised (Prabhu, 1990): method is a tool in the hand of carpenter. She can make furniture on the basis of her skills. Similarly, teacher also selects his own activity to make the best. So, one can't suggest the best method to others.

IV. Redundancy: first she talks about the experiences of the class and again she describes about in the observation and principles. She further describes the same in reviewing the principles in 10 questions and techniques which is redundant.

V. Parts of the book: index and glossary part is missing in the book which is really essential for the novice learners or teachers.

\section{Suggestions and recommendations}

Method does not deskill the teachers. It rather helps them articulate and transfer their understanding of teaching and learning process. Since a method is more abstract than a teaching and learning activities, we should not follow it as a recipe for preparing a food because how to implement in the classroom depends on nature, background of the student, teachers expectations, institutional constrain, sociopolitical inequalities and socio-cultural context. Therefore, my suggestion is to follow the eclectic method that fits into your classroom.

Borrowing the word from series editor, I want to say that this book is her serious and deeply personal thought devoted to complex pedagogical issues and her incomparable ability to make this matter come alive with great clarity for the widest professional readership. 